\title{
Modern seasonal variability and deglacial/Holocene change of central Arctic Ocean sea-ice cover: New insights from biomarker proxy records
}

\author{
Kirsten Fahl*, Ruediger Stein \\ Alfred Wegener Institute for Polar and Marine Research, Am Alten Hafen 26, 27568 Bremerhaven, Germany
}

\section{A R T I C L E I N F O}

\section{Article history:}

Received 16 February 2012

Received in revised form

6 July 2012

Accepted 7 July 2012

Editor: J. Lynch-Stieglitz

\section{Keywords:}

Arctic Ocean

sea ice

biomarker

$\mathrm{IP}_{25}$

Younger Dryas

sediment trap

\begin{abstract}
A B S T R A C T
For the reconstruction of sea-ice variability, a biomarker approach which is based on (1) the determination of sea-ice diatom-specific highly-branched isoprenoid $\left(\mathrm{IP}_{25}\right)$ and $(2)$ the coupling of phytoplankton biomarkers and $\mathrm{IP}_{25}$ has been used. For the first time, such a data set was obtained from an array of two sediment traps deployed at the southern Lomonosov Ridge in the central Arctic Ocean at water depth of $150 \mathrm{~m}$ and $1550 \mathrm{~m}$ and recording the seasonal variability of sea ice cover in 1995/1996. These data indicate a predominantly permanent sea ice cover at the trap location between November 1995 and June 1996, an ice-edge situation with increased phytoplankton productivity and sea-ice algae input in July/ August 1996, and the start of new-ice formation in late September. The record of modern sea-ice variability is then used to better interpret data from sediment core PS2458-4 recovered at the Laptev Sea continental slope close to the interception with Lomonosov Ridge and recording the post-glacial to Holocene change in sea-ice cover.

Based on $\mathrm{IP}_{25}$ and phytoplankton biomarker data from Core PS2458-4, minimum sea-ice cover was reconstructed for the Bølling/Allerød warm interval between about 14.5 and 13 calendar kyr BP, followed by a rapid and distinct increase in sea-ice cover at about 12.8 calendar kyr BP. This sea-ice event was directly preceded by a dramatic freshwater event and a collapse of phytoplankton productivity, having started about 100 years earlier. These data are the first direct evidence that enhanced freshwater flux caused enhanced sea-ice formation in the Arctic at the beginning of the Younger Dryas. In combination with a contemporaneous, abrupt and very prominent freshwater/meltwater pulse in the Yermak Plateau/ Fram Strait area these data may furthermore support the hypothesis that strongly enhanced freshwater (and ice) export from the Arctic into the North Atlantic could have played an important trigger role for the onset of the Younger Dryas cold reversal. During the Early Holocene, sea-ice cover steadily increased again (ice-edge situation), reaching modern sea-ice conditions (more or less permanent sea-ice cover) probably at about 7-8 calendar kyr BP.
\end{abstract}

(c) 2012 Elsevier B.V. All rights reserved.

\section{Introduction and background}

An important phenomenon of the Arctic Ocean is the sea-ice cover with its strong seasonal variability in the marginal (shelf) areas (Fig. 1 and supplementary material, Fig. S1; Johannessen et al., 2004 and further references therein). Sea ice is a very critical component of the Arctic system that responds sensitively to changes in atmospheric circulation, incoming radiation, atmospheric and oceanic heat fluxes, as well as the hydrological cycle. Ice significantly reduces the heat flux between ocean and atmosphere; through its high albedo it has a strong influence on the radiation budget of the entire Arctic. Thus, sea ice certainly plays a substantial role in climate system variability. Furthermore, the sea-ice cover strongly affects the biological productivity, as

\footnotetext{
* Corresponding author. Tel.: +49 4714831 1578; fax: +4947148311923.

E-mail address: kirsten.fahl@awi.de (K. Fahl).
}

a more closed sea-ice cover restricts primary production due to low light influx in the surface waters. Sea ice is also an important agent for sediment transport from the shelves into, across, and out of the Arctic Ocean (for review see Stein, 2008).

There is a general consensus that the polar regions-and especially the Arctic Ocean and surrounding areas-are (in real time) and have been (over historic and geologic time scales) subject to rapid and dramatic change. The Arctic sea ice, for example, had been undergoing retreat over the past three decades with an extreme minima in 2007, recognized by the science community with some alarm (e.g., Johannessen et al., 2004; Francis et al., 2005; Serreze et al., 2007; Stroeve et al., 2007). The causes of the recent changes, however, are a subject of intense scientific and environmental debate. As outlined by Johannessen et al. (2004), it remains open to debate whether the warming and decrease in sea ice over the recent decades are an enhanced greenhouse-warming signal or-at least partly-natural decadal and multidecadal climate variability (Polyakov and Johnson, 2000; 

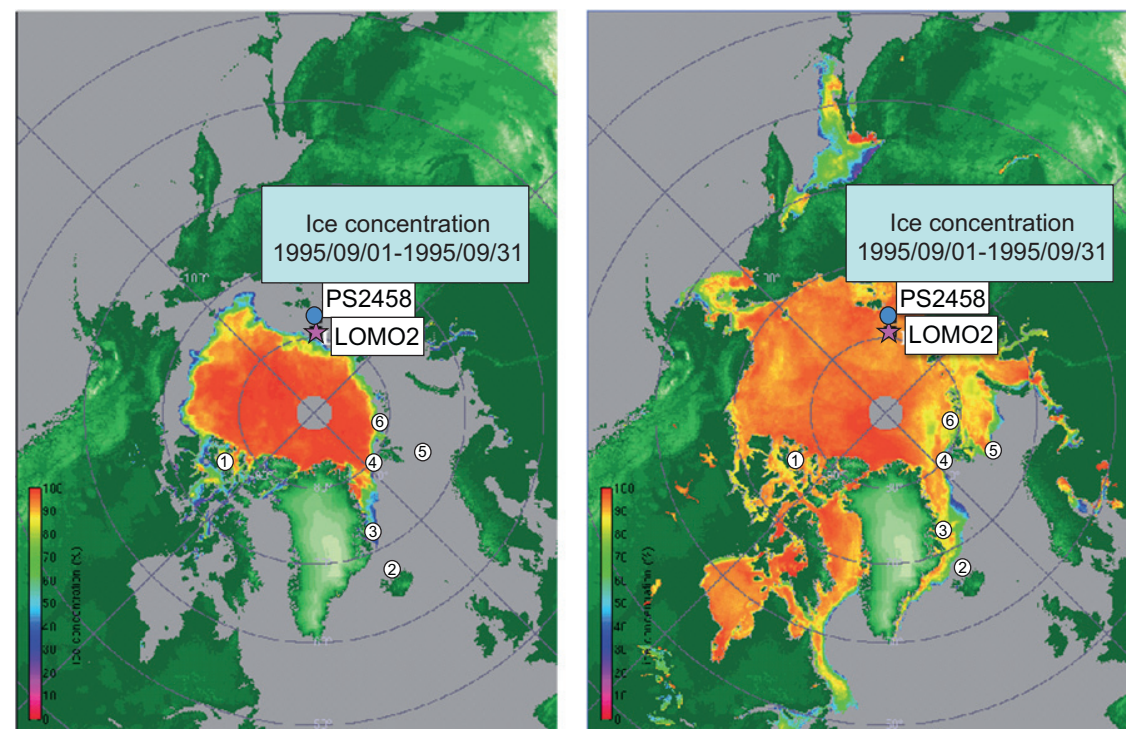

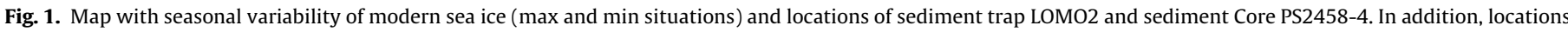

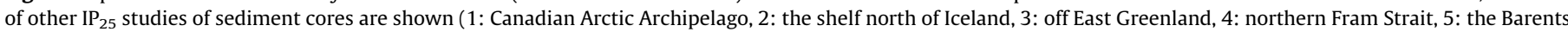
Sea, and 6: Barents Sea continental slope). For references of these studies see text.

Source: http://iup.physik.uni-bremen.de:8084/amsr/regions.html.

Polyakov et al., 2002). The uncertainties in statements related to causes of recent climate change and its extrapolation into the future are in part related to the lack of homogeneous, century-scale instrumental data sets needed to resolve the inherent timescales of variability in the Arctic (Venegas and Mysak, 2000), a region characterized by high variability. Here, we present high-resolution paleo-sea ice as well as other paleoclimatic records going back beyond the timescale of direct measurements.

Concerning the reconstruction of paleo-sea ice distributions, a novel biomarker approach, which is based on the determination of sea-ice diatom-specific highly branched isoprenoid ( $C_{25}$ HBI monoene $=\mathrm{IP}_{25}$ ), has been developed by Belt et al. (2007). In following-up studies, the identification of this biomarker proxy $\mathrm{IP}_{25}$ in marine sediment cores from the Canadian Arctic Archipelago (Belt et al., 2008, 2010; Vare et al., 2009), the shelf north off Iceland (Massé et al., 2008), the Barents Sea (Vare et al., 2010) and from northern Fram Strait and off East Greenland (Müller et al., 2009, 2011, 2012) allowed reconstructions of the ancient sea ice variability in these regions during last $1-30 \mathrm{ka}$ (see Fig. 1 for location of cores/study areas $1-5$ ). In a pilot study carried out in a sediment core from the Barents Sea continental slope (see Fig. 1, location 6), Stein et al. (submitted for publication) could show that $\mathrm{IP}_{25}$ is even preserved in sediments as old as $130-150 \mathrm{ka}$ (MIS 6), i.e., $\mathrm{IP}_{25}$ can be used for reconstruction of sea-ice variability during older glacial/interglacial intervals (MIS 6/MIS5).

When using $\mathrm{IP}_{25}$ as sea-ice proxy one has to consider that its absence may refer to either a lack of sea ice or, in contrast, a permanent and thick ice cover limiting any algal growth. In this context, the combination of $\mathrm{IP}_{25}$ with a phytoplankton marker (in terms of a phytoplankton marker-IP ${ }_{25}$ index $\mathrm{PIP}_{25}$; Müller et al., 2011) proves highly valuable to properly interpret the sea-ice proxy signal as an under- or overestimation of sea-ice coverage can be circumvented and more quantitative estimates of paleo-sea-ice coverage seem to be possible (Müller et al., 2009, 2011, 2012).

Here, we present new $\mathrm{IP}_{25}$ and phytoplankton biomarker (and calculated $\mathrm{PIP}_{25}$ ) data (1) from a sediment trap deployed at the southern Lomonosov Ridge in the central Arctic Ocean and recording the seasonal variability in sediment and biomarker fluxes in 1995/ 1996 (Fahl and Nöthig, 2007), and (2) from a sediment core recovered at the Laptev Sea continental slope close to the interception with Lomonosov Ridge and recording the post-glacial to Holocene paleoenvironmental change (Fahl and Stein, 1999; Stein and Fahl, 2004; Spielhagen et al., 2005) (Fig. 1).

\section{Material and methods}

\subsection{Sediment trap: background information}

During the Polarstern Expedition ARK-XI/1 in 1995 (Rachor, 1997), a long-term mooring system with two cone-shaped multisampling traps (SMT 230 K.U.M.; sampling area $0.5 \mathrm{~m}^{2}$ ) was deployed at the dominantly ice-covered western slope of the southern Lomonosov Ridge (Fig. 1, LOMO2; $81^{\circ} 04.5^{\prime} \mathrm{N}, 138^{\circ} 54.0^{\prime} \mathrm{E}$, $1712 \mathrm{~m}$ water depth). One trap was installed at $150 \mathrm{~m}$ below the sea surface, the other at $150 \mathrm{~m}$ above the bottom at $1550 \mathrm{~m}$ depth; material was collected in 20 time intervals between September 1995 and August 1996. This allowed for the first time to study changes in vertical fluxes, degradation processes and lateral input in the High Arctic. Further details are described in Fahl and Nöthig (2007).

\subsection{Core PS2458-4: sediments and age model}

Core PS2458-4 was recovered from the upper eastern Laptev Sea continental slope $\left(78^{\circ} 09.95^{\prime} \mathrm{N}, 133^{\circ} 23.86^{\prime} \mathrm{E}\right.$; water depth $983 \mathrm{~m}$ ) during Polarstern Cruise ARK-IX/4 and consists of a $8 \mathrm{~m}$ long sedimentary sequence of dominantly very dark olive-gray silty clay of dominantly terrigenous origin (Fütterer, 1994). Small bivalves occasionally occur and were used for AMS $-{ }^{14} \mathrm{C}$ dating (Spielhagen et al., 1996, 2005). Based on these AMS $-{ }^{14} \mathrm{C}$ datings, a very reliable chronology is available for the sediment interval between about 250 and $650 \mathrm{~cm}$ below seafloor (cmbsf), representing a time interval between about 9.3 and 14.7 calendar kyr BP (for discussion of the age model see Spielhagen et al., 2005). For this well-dated interval, data were also plotted versus age (see below). The base of the core has an extrapolated age of about 16.4 calendar kyr BP. For the upper $250 \mathrm{cmbsf}$, two age models are discussed. The published age model by Spielhagen et al. (2005) included the AMS ${ }^{14} \mathrm{C}$ age of a piece of wood found in $201 \mathrm{cmbsf}$ (8.85 calendar kyr BP). These authors are aware that wood pieces bear some risk of being redeposited, however, the date fits 
with an almost linear extrapolation of results from samples below and hence is regarded as a reliable date. Furthermore, there seems to be some evidence of a hiatus at a depth of $100 \mathrm{cmbsf}$, lasting from about 8 calendar kyr BP to about 0.1-0.2 calendar kyr BP (Spielhagen et al., 2005). For the alternative age model discussed below, we only used the AMS $-{ }^{14} \mathrm{C}$ datings from bivalves, i.e., we assume linear sedimentation rates (and no hiatus) between the AMS- ${ }^{14} \mathrm{C}$ datings at $252 \mathrm{cmbsf}$ (9.29 calendar kyr BP) and $0 \mathrm{cmbsf}$ ( 0 calendar kyr $\mathrm{BP}=$ recent). This age model results in significantly reduced sedimentation rates at about 9.3 calendar kyr BP. Such a drastic decrease in sedimentation rates between 9 and 10 calendar kyr BP is also reported in numerous sediment cores from the Laptev Sea and Kara Sea continental shelf and upper slope, explained by a shift of the main depocenter towards the inner shelf due to the onset of shelf flooding at that time (Bauch et al., 2001b; Stein et al., 2004; Stein and Fahl, 2004; Taldenkova et al., 2010). This contemporaneous decrease in sedimentation rates along the Laptev and Kara seas continental margin may be a strong argument for the alternative age model.

\subsection{Biomarker analyses}

All sediment samples for the organic geochemical analysis were stored at $-30{ }^{\circ} \mathrm{C}$ directly after collecting. The treatment of the sediment trap samples has been published by Fahl and Nöthig (2007). For biomarker analyses of the Core PS2458-4 ca. 6-8 g of freeze-dried and homogenized sediment were extracted by an Accelerated Solvent Extractor (DIONEX, ASE 200; $100{ }^{\circ} \mathrm{C}, 5 \mathrm{~min}$, $1000 \mathrm{psi})$ using dichloromethane:methanol $(2: 1 \mathrm{v} / \mathrm{v})$. The freezedrying as well as the extraction method have been tested for reproducibility and stability of compounds using a reference sediment and standards of several organic substances, e.g., brassicasterol, campesterol, $\beta$-sitosterol, a homologous series of $n$-alkanes, mono- and polyunsaturated fatty acids $\left(\mathrm{C}_{16}-\mathrm{C}_{22}\right)$ as well as the below mentioned internal standards, characterized by similar chemical properties as the analytes. With the exception of the volatility of the short-chain $n$-alkanes (up to and including $C_{16} n$-alkane, which is not the scope of this study) no impact could be detected. For quantification the internal standards 7-hexylnonadecane $(0.076 \mu \mathrm{g} / \mathrm{sample})$, squalane $(2.4 \mu \mathrm{g} / \mathrm{sample})$ and cholesterol- $\mathrm{d}_{6}$ (cholest-5-en-3 $\beta$-ol- $\mathrm{D}_{6} ; 22 \mu \mathrm{g} / \mathrm{sample}$ ) were added before any analytical treatment. Thus, quantification errors caused by loss of analytes, systematic errors during the chemical treatment and/or instrument measurement can be excluded. The compounds were separated by column chromatography using $\mathrm{SiO}_{2}$ as stationary phase. Hydrocarbons were eluted with $n$-hexane $(5 \mathrm{ml})$ and sterols with ethylacetate: $n$-hexane $(20: 80 \mathrm{v} / \mathrm{v} ; 6 \mathrm{ml})$. The latter fraction was silylated with $500 \mu \mathrm{l}$ BSTFA (bis-trimethylsilyl-trifluoroacet-amide) $\left(60{ }^{\circ} \mathrm{C}, 2 \mathrm{~h}\right)$. The composition of the hydrocarbons and sterols was analyzed by gas chromatography (GC) using an Agilent $6850(30 \mathrm{~m}$ HP-5MS column, $0.25 \mathrm{~mm}$ i.d., $0.25 \mu \mathrm{m}$ film thickness) coupled to an Agilent 5975C VL mass selective detector (MSD, $70 \mathrm{eV}$ constant ionization potential, Scan $50-550 \mathrm{~m} / z, 1 \mathrm{scan} / \mathrm{s}$, ion source temperature $230^{\circ} \mathrm{C}$ ). GC analyses were performed with the following temperature program for the hydrocarbons: $60{ }^{\circ} \mathrm{C}(3 \mathrm{~min}), 150{ }^{\circ} \mathrm{C}$ (rate: $15^{\circ} \mathrm{C} / \mathrm{min}$ ), $320^{\circ} \mathrm{C}$ (rate: $\left.10{ }^{\circ} \mathrm{C} / \mathrm{min}\right), 320^{\circ} \mathrm{C}(15 \mathrm{~min}$ isothermal) and for the sterols: $60{ }^{\circ} \mathrm{C}(2 \mathrm{~min}), 150{ }^{\circ} \mathrm{C}$ (rate: $15^{\circ} \mathrm{C} / \mathrm{min}$ ), $320{ }^{\circ} \mathrm{C}$ (rate: $\left.3{ }^{\circ} \mathrm{C} / \mathrm{min}\right), 320{ }^{\circ} \mathrm{C}$ (20 min isothermal). The injection volume was $1 \mu \mathrm{l}$ splitless. Helium was used as carrier gas $(1 \mathrm{ml} / \mathrm{min}$ constant flow).

The identification of the hydrocarbons and the sterols was carried out on basis of GC retention time and fragmentation pattern obtained from mass spectrometry (MS). The latter has been compared with published mass spectra (for sterols see Boon et al. (1979) and Volkman (1986), for $\mathrm{IP}_{25}$ see Belt et al. (2007), and for $\mathrm{C}_{25}-\mathrm{HBI}$ diene see Johns et al. (1999)). The Kovats Index calculated for $\mathrm{IP}_{25}$ is 2085 (under the above mentioned conditions), retention indices for brassicasterol (as 24-methylcholesta-5,22E-dien-3 $\left.\beta-\mathrm{O}-\mathrm{Si}\left(\mathrm{CH}_{3}\right)_{3}\right)$, campesterol (as 24-methylcholest-5-en-3 $\beta-\mathrm{O}-\mathrm{Si}\left(\mathrm{CH}_{3}\right)_{3}$ ) and $\beta$-sitosterol (as 24-ethylcholest-5-en-3 $\left.\beta-\mathrm{O}-\mathrm{Si}\left(\mathrm{CH}_{3}\right)_{3}\right)$ were calculated to be 1.018 , 1.042 , and 1.077 (normalized to cholest-5-en-3 $\beta-$ ol- $_{6}$ set to be 1.000 ), respectively.

The concentrations of the biomarker were calculated on the basis of their individual GC-MS (gas chromatography-mass spectrometry) ion responses compared with those of respective internal standards. All sterols were quantified as trimethylsilyl ethers (-OTMS) using the molecular ions $m / z 470$ for brassicasterol, $m / z 472$ for campesterol, and $m / z 486$ for $\beta$-sitosterol, compared with the response of the molecular ion $\mathrm{m} / \mathrm{z} 464$ of the internal standard cholesterol- $\mathrm{d}_{6}$.

For the quantification of $\mathrm{IP}_{25}$ and $\mathrm{C}_{25}-\mathrm{HBI}$ diene their molecular ions ( $m / z 350$ for IP25, $m / z 348$ for $C_{25}-\mathrm{HBI}$ diene) in relation to the abundant fragment ion $m / z 266$ of the internal standard (7-hexylnonadecane, 7-HND) were used. All these ions for themselves fulfill the qualification of having a linear behavior concerning response and concentration in both total ion current (TIC) mode (the ions were extracted from the total ion current) and selected ion monitoring (SIM) mode (see supplementary material, Fig. S2B-E). To calculate a calibration factor in order to balance the different responses of $m / z 350\left(\mathrm{IP}_{25}\right)$ and $m / z 266$ (7-HND) an indirect route was used to circumvent the (during our data acquisition) unavailable synthetically produced analyte $\mathrm{IP}_{25}$. A sediment sample with high $\mathrm{IP}_{25}$ concentration (and without coelution of other compounds) was quantified via TIC (using MSD) and gas chromatography (see supplementary material, Fig. S2A for comparison) and posed as substitute for the $\mathrm{IP}_{25}$ standard of known concentration for proceeding with an external calibration. As next step, a calibration curve $\left(r^{2}=0.99\right)$ has been established (see supplementary material, Fig. S2F).

The biomarker concentrations were corrected to the amount of extracted sediment.

The qualification and quantification of the fatty acids cis-9hexadecenoic acid $\left(\mathrm{C}_{16: 1(n-7)}\right)$, cis-11-hexadecenoic acid $\left(\mathrm{C}_{16: 1(n-5)}\right)$, and all-cis-5,8,11,14,17-eicosapentaenoic acid $\left(C_{20: 5(n-3)}\right)$ of the sediment trap were already published by Fahl and Nöthig (2007). All data are available on doi:10.1594/PANGAEA.602289.

Supplementary data for this publication are available at doi:10.1594/PANGAEA.775891.

\subsection{Calculation of $P I P_{25}$ Index}

Following Müller et al. (2011) we combined the $\mathrm{IP}_{25}$ with the phytoplankton biomarker brassicasterol and calculated the phytoplanktion- $\mathrm{IP}_{25}$ index $\left(\mathrm{PIP}_{25}\right.$ index) that seems to be highly valuable to properly interpret the sea ice proxy signal as an under- or overestimation of sea ice coverage can be circumvented. Regarding the significant concentration difference between $\mathrm{IP}_{25}$ and brassicasterol, we considered a balance factor $F$ (calculated by the average concentrations of both marker, see below) for the calculation of the $\mathrm{PIP}_{25}$ index (see Müller et al., 2011):

$\mathrm{PIP}_{25}=\mathrm{IP}_{25} /\left(\mathrm{IP}_{25}+(\right.$ brassicasterol $\times F)$

For mean brassicasterol and $\mathrm{IP}_{25}$ values determined in the two sediment trap records (average of the entire year) as well as the Core PS2458-4 record (average of the entire core) we calculated the following $F$ values:

$F_{\text {shallow trap }}=0.00079251, \quad F_{\text {deep trap }}=0.00077532$, and

$F_{\text {Core PS2458 }}=0.05429$ (for data base see pangaea.de)

When using the $\mathrm{PIP}_{25}$ index to distinguish between different sea ice conditions, however, it requires essential awareness of the individual biomarker concentrations to avoid misleading interpretations as outlined by Müller et al. (2011) in more detail. Although the 
$\mathrm{PIP}_{25}$ approach still has its limitations and needs further validation with additional data from other Arctic areas, the main and principle idea of pairing $\mathrm{IP}_{25}$ with a phytoplankton productivity measure to distinguish between multiple ice conditions characterized by zero $\mathrm{IP}_{25}$ (as introduced by Müller et al. 2009, 2011), remains an important further development of the original $\mathrm{IP}_{25}$ approach.

\section{Results and discussion}

3.1. Seasonal variability of sea ice cover as deduced from biomarker sediment trap data

Concerning modern central Arctic Ocean particulate (lithogenic and biogenic) fluxes, Fahl and Nöthig (2007) presented the first record of the annual variability and composition of particle fluxes in the Lomonosov Ridge area close to the Laptev Sea continental margin. These authors discussed data on the variability of fluxes of lithogenic matter, $\mathrm{CaCO}_{3}$, opal (including data on diatom assemblages), and particulate organic carbon as well as specific biomarker composition ( $n$-alkanes, fatty acids, and terrestrial sterols), and found that both the shallow and the deep trap showed significant variations in vertical organic and lithogenic fluxes over the year $1995 / 1996$. For example, distinctly higher particulate organic carbon (POC) values were found from mid-July to the end of October (POC mass flux of $1-15 \mathrm{mg} \mathrm{m}^{-2} \mathrm{~d}^{-1}$ in the shallow trap and 3-9 $\mathrm{mg} \mathrm{m}^{-2} \mathrm{~d}^{-1}$ in the deep trap) whereas during all other months (i.e., November-June), fluxes were fairly low in both traps (most POC mass flux values $<3 \mathrm{mg} \mathrm{m}^{-2} \mathrm{~d}^{-1}$ ) (Figs. 2 and 3). In general, the former time interval of increased fluxes coincided with times of reduced sea ice whereas the latter time interval characterized by reduced fluxes is related to a period of closed sea ice cover. In order to get more detailed information about the sea ice cover and its change throughout the year, in this study we have focused on the novel sea ice proxy $\mathrm{IP}_{25}$ and the phytoplankton- $\mathrm{IP}_{25}$ index (PIP $_{25}$ Index) (Fig. 2; Belt et al., 2007; Müller et al., 2009, 2011).
The interval November 1995-June 1996 classified by Fahl and Nöthig (2007) as period of predominantly permanent sea ice cover, is characterized by the absence of the sea-ice proxy $\mathrm{IP}_{25}$ (except very minor values for February and April in the upper sediment trap; Fig. 3), supporting these authors' interpretation in general. Based on diatom assemblages determined in the trap samples, however, a first ice-algal growth already started at the end of April to the beginning of May, reflected in low/rare abundances of ice-associated algal community (Nitzschia species) and paralleled by a first increase in POC flux (Fig. 3). The absence (to very low abundance during April in the upper sediment trap) in $\mathrm{IP}_{25}$ in this time interval may be caused by the fact that the Haslea species, as one possible producers of $\mathrm{IP}_{25}$, only present a very minor proportion of this sub-ice algae community $(<0.1 \%$, Nöthig and Zernova, unpublished data). In April, low abundances of brassicasterol and fatty acids were also found in the upper sediment trap (Fig. 3), suggesting some first phytoplankton productivity in open-water leads. Both biomarkers, however, also occurred in minor (background) amounts in both sediment traps throughout the winter (dark) period, which may suggest a release of the biomarkers trapped in the sea ice (cf., Fahl and Nöthig, 2007). Furthermore, the general decrease in biomarker concentrations from the shallow to the deep sediment trap may be related to degradation processes (see below). The distinct maximum in brassicasterol determined in the upper trap for February (Fig. 3), i.e., during winter times of total darkness and closed sea-ice cover, cannot be explained so far.

Then, in June-August (September), abundant sub-ice algal species of Nitzschia frigida, N. promare, Gyrosigma spec., and Melosira arctica occurred in the shallow trap (Zernova et al., 2000; Fahl and Nöthig, 2007). The high cell numbers with intact cells of these species more or less exactly coincide with maximum values of $\mathrm{IP}_{25}$ values. During this time interval between June and August, on the other hand, also maximum abundances of pelagic/open-ocean diatoms, mainly Fragilariopsis oceanica, were determined. The absolute maximum in diatom abundances in August 1996 was caused by the pennate diatoms $F$. oceanica (open ocean indicator) and $N$. frigida (sub-ice algae) (Zernova et al., 2000).

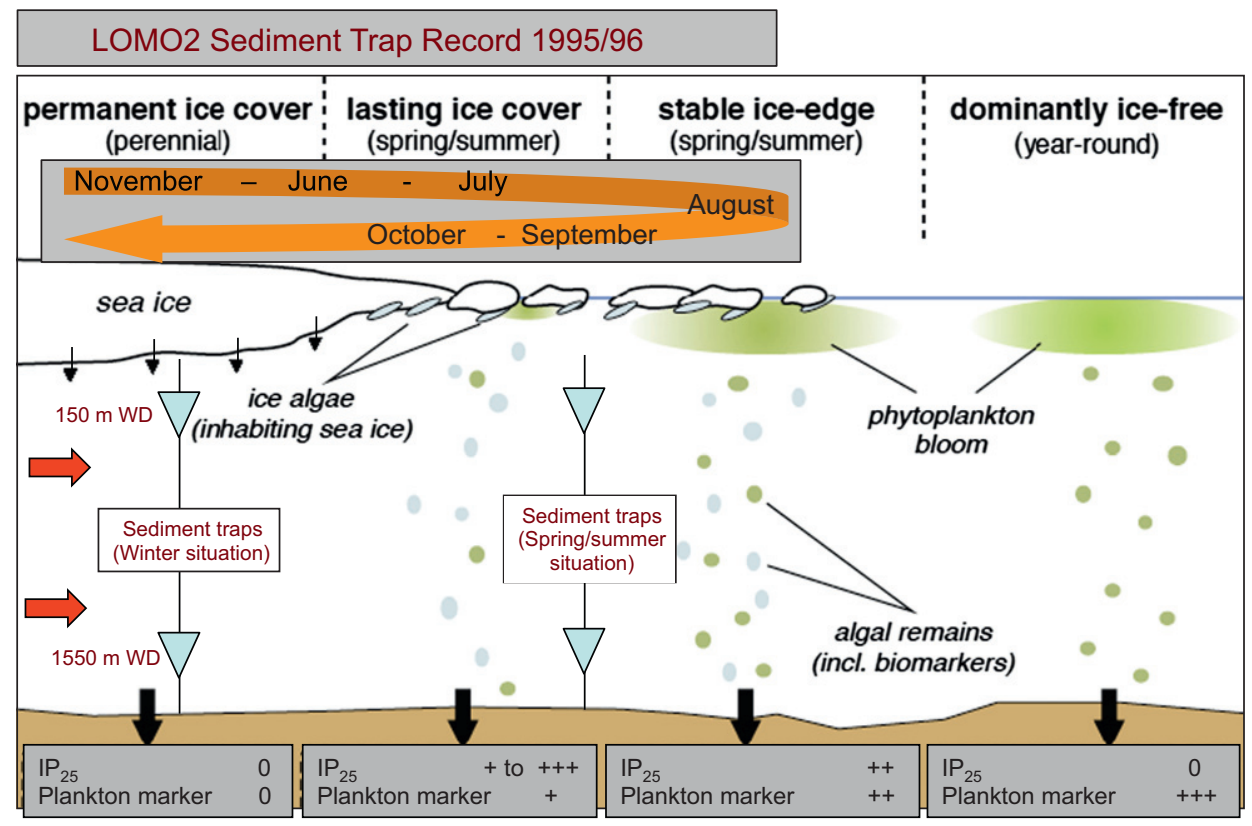

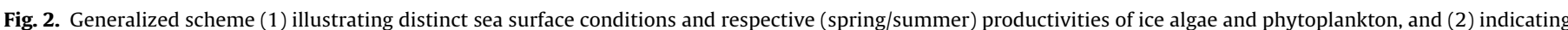

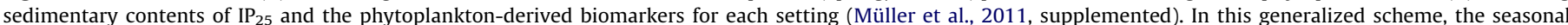

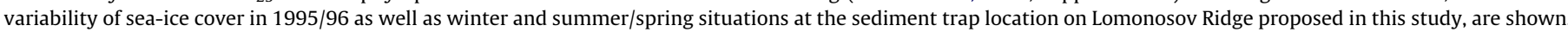

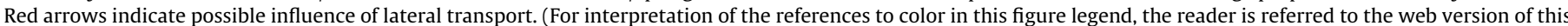
article.) 


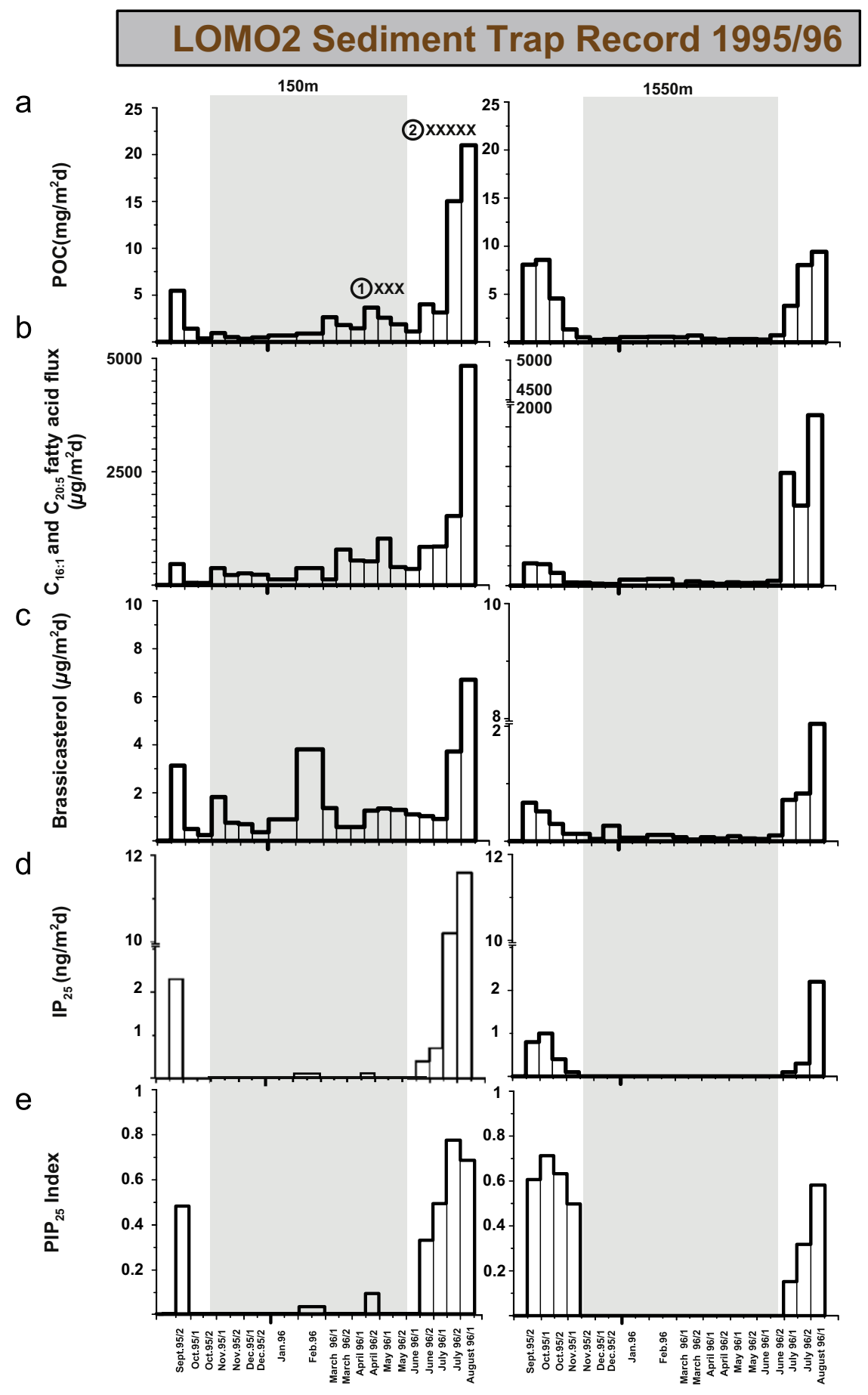

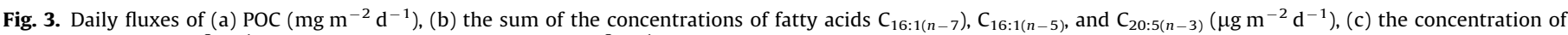

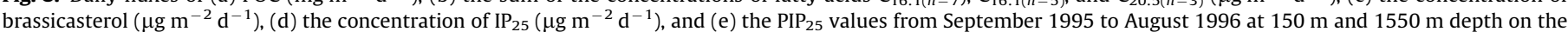

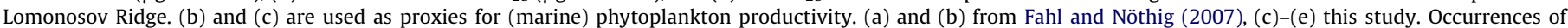

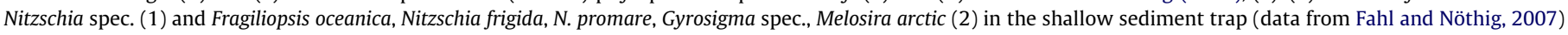
are indicated by crosses.

The high abundances of diatoms during July/August are supported by the maximum fluxes of the diatom-specific fatty acids and brassicasterol (Fig. 3) as well as maximum contents of biogenic opal in both traps (Fahl and Nöthig, 2007), all related to increased primary productivity. The marine organic matter (here POC, brassicasterol, and fatty acids) and the $\mathrm{IP}_{25}$ values decrease systematically from 150 to $1550 \mathrm{~m}$ depth (Fig. 3), indicating a possible biogeochemical degradation with increasing water depth and/or an incorporation of organic carbon including $\mathrm{IP}_{25}$ and brassicastrol into the marine food web (Brown and Belt, 2012; Brown et al., 2012). The maximum August $1996 \mathrm{IP}_{25}$ concentration decreased from about $12 \mathrm{ng} \mathrm{m}^{-2} \mathrm{~d}^{-1}$ to about $2 \mathrm{ng} \mathrm{m}^{-2} \mathrm{~d}^{-1}$ during its fall through the water column from 150 (shallow trap) to $1550 \mathrm{~m}$ (deep trap) water depth, i.e., decreased by a factor of about six, whereas brassicasterol decreased by a factor of four to five. That means, the change in $\mathrm{PIP}_{25}$ values (as calculated as ratio from both biomarkers) with increasing water depth is smaller than the changes of the single biomarker. This decrease in concentration 
during transfer through the water column has to be considered when interpreting the absolute $\mathrm{IP}_{25}$ and brassicasterol concentrations as well as the $\mathrm{PIP}_{25}$ ratios in sedimentary records. Furthermore, these organic fluxes in July/August suggest that vertical flux processes mainly controlled the biomarker values measured in the deep trap during July and August, instead of the lateral input which controlled fluxes during September/October (Fahl and Nöthig, 2007; see also below).

Due to the coincidence of maximum abundances of sea-ice proxies and open-ocean primary productivity proxies during the July/August time interval we propose an ice-edge situation characterized by increased phytoplankton productivity and sea-ice algae input (Fig. 2; Sakshaug, 2004; Müller et al., 2011), versus the fully ice-free conditions originally proposed by Fahl and Nöthig (2007). Our interpretation is also supported by the phytoplankton- $\mathrm{IP}_{25}$ index $\left(\mathrm{PIP}_{25}\right.$ Index), reaching quite high values of $0.5-0.8$ (Fig. 3; Müller et al., 2011).

During September/October, concentrations of POC (Fig. 3) and terrigenous biomarkers (Fahl and Nöthig, 2007) reached significantly higher in the deep trap in comparison to the shallow trap. This has been interpreted by Fahl and Nöthig (2007) as increased lateral sediment flux at greater depth, related to increased terrigenous sediment input from the Kara and Laptev seas with transport by sea-ice transport and/or (contour) currents. Brassicasterol and fatty acid concentrations (as phytoplankton productivity indicators), on the other hand, still seems to be controlled by vertical flux processes as indicated by the normal decrease in concentrations with increasing water depth (Fig. 3). The distinctly reduced September/October values of brassicasterol and fatty acids suggest a decrease in primary productivity, probably related to the start of new-ice formation in late September (Fig. 2). This situation is reflected in $\mathrm{IP}_{25}$ values of $2 \mathrm{ng} \mathrm{m}^{-2} \mathrm{~d}^{-1}$ (which are lower in comparison with July/August but still high enough to indicate the occurrence of sea-ice diatoms) and a $\mathrm{PIP}_{25}$ ratio of 0.5 (Figs. 2 and 3) in the shallow trap. These data indicate, that different processes (i.e., vertical vs. lateral sediment input) have probably controlled the biogenic and terrigenous sediment fluxes in autumn (see Fahl and Nöthig, 2007).

\subsection{Change in deglacial to Holocene sea ice cover as deduced from} biomarker records of Core PS2458-4

For characterization of the different organic carbon sources (i.e., marine vs. terrigenous) and interpretation of the data in terms of paleoenvironmental changes, several studies have been carried out in the past on the organic-carbon fraction of Core PS2458-4 (Fahl and Stein, 1999; Stein et al., 2001; Boucsein et al., 2002; Stein and Fahl, 2004). Furthermore, Spielhagen et al. (2005) carried out a study of oxygen and carbon isotopes of the planktic foraminifer species Neogloboquadrina pachyderma sin. in order to reconstruct the freshwater runoff in the Laptev Sea during the last deglaciation. None of these studies, however, have concentrated on the deglacial to Holocene history of sea-ice cover, the major focus of this study.

The sedimentary record of Core PS2458-4 probably represents the last about 16.5 calendar kyr BP. During this time interval, the sea level rose by about $110 \mathrm{~m}$ (e.g., Fairbanks, 1989), and major parts of the broad Laptev Sea shelf became flooded (Fig. 4; Stein and Fahl, 2000; Bauch et al., 2001b). This post-glacial sea-level rise (resulting in an increase of distance between river mouth and core location) is also reflected in distinct continuous decrease of the terrigenous biomarker campesterol and ß-sitosterol whereas at the same time the phytoplankton biomarker brassicasterol increased (Fig. 5). During the upper $250 \mathrm{cmbsf}$, however, brassicasterol decreased, a change probably triggered by an increase in sea-ice cover (see discussion below). The sea-ice biomarkers IP $_{25}$
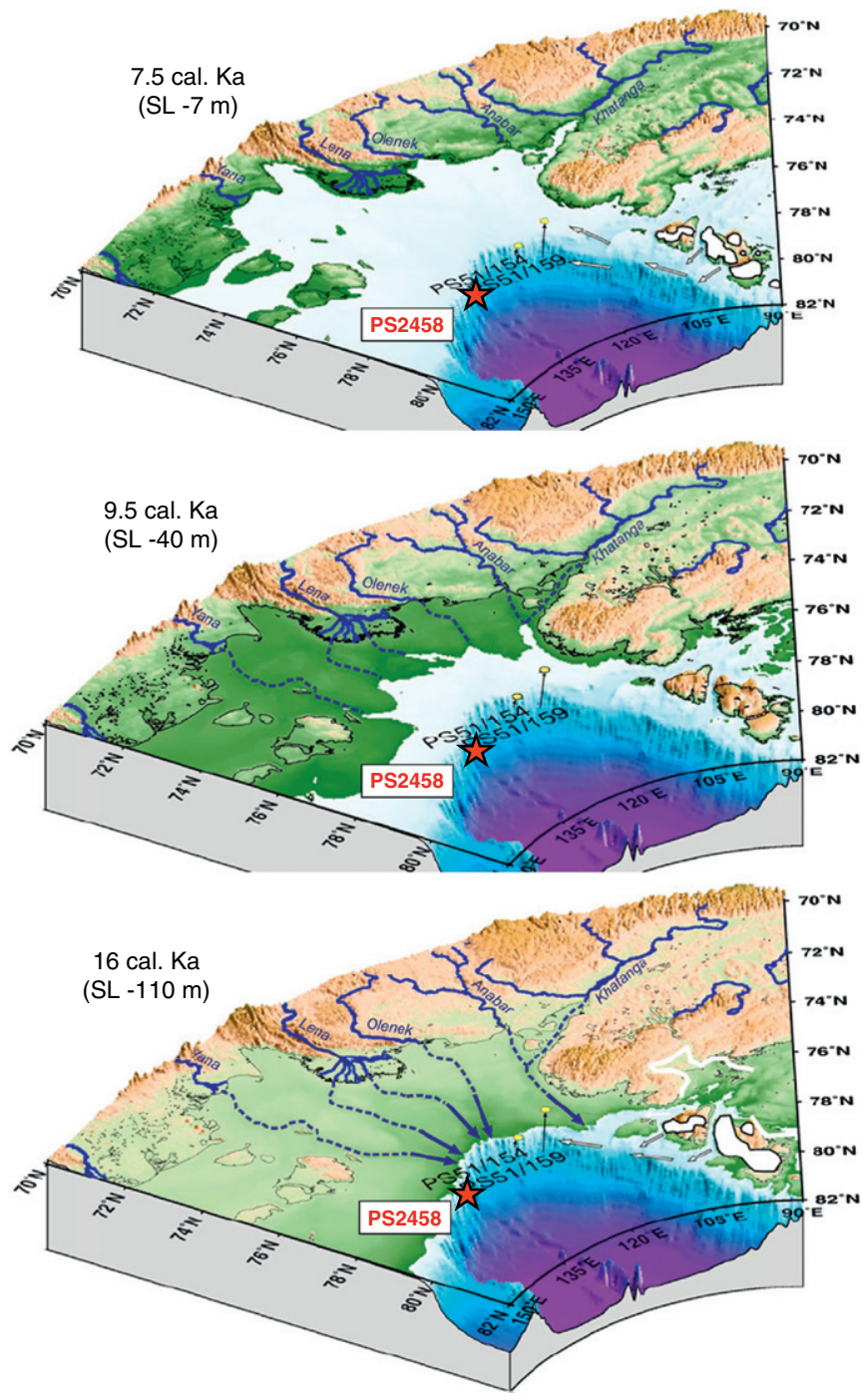

Fig. 4. Schemes of reconstructed paleoenvironment of the western Laptev Sea based on sea-level data from Fairbanks (1989) and Bauch et al. (2001b), and bathymetric data from. GEBCO (http://www.gebco.net). (a) Glacial-like environment prior to the onset of shelf flooding and with ice caps on Severnaya Zemlya. White contours show the established limits of the Barents-Kara ice sheet extension in the northeastern Kara Sea during the LGM (Svendsen et al., 2004). (b) Progressing shelf flooding (situation at 9.5 calendar kyr BP), past environment with seasonal sea ice cover. Ice caps on Severnaya Zemlya might be reduced in size or absent. (c) Modern-like environment established at the continental margin since about 7 calendar kyr BP, with re-growth of ice caps on Severnaya Zemlya and iceberg production. Proposed ice caps on Severnaya Zemlya and possible directions of iceberg discharge during phases (a) and (c) are shown as white fields and, respectively. Locations of cores studied by Taldenkova et al. (2010) and Core PS2458-4 are shown. Figure from Taldenkova et al. (2010), supplemented.

and $\mathrm{PIP}_{25}$ show a long-term increase from minimum values between 650 and $520 \mathrm{cmbsf}(14.7-12.8$ calendar kyr BP) to maximum values typical for the upper $250 \mathrm{cmbsf}$ (age $<9.3$ calendar kyr BP), suggesting a continuous general increase in sea-ice cover towards the Holocene and throughout. A small but significant maximum at 780-760 cmbsf interpreted as short phase of more extended sea-ice cover, may coincide with the cold Heinrich Event 1, if using the extrapolated age of 16.4 calendar kyr BP (Fig. 5).

In addition to $\mathrm{IP}_{25}$, the $\mathrm{HBI}$ diene $\left(\mathrm{C}_{25: 2}\right)$ was determined in the sediment samples from Core PS2458-4 as well. This isomer has been found in marine sediments from both the Arctic Ocean and the Southern (polar) Ocean but also in more temperate regions (Belt et al., 2007; Vare et al., 2009; Massé et al., 2011), suggesting 


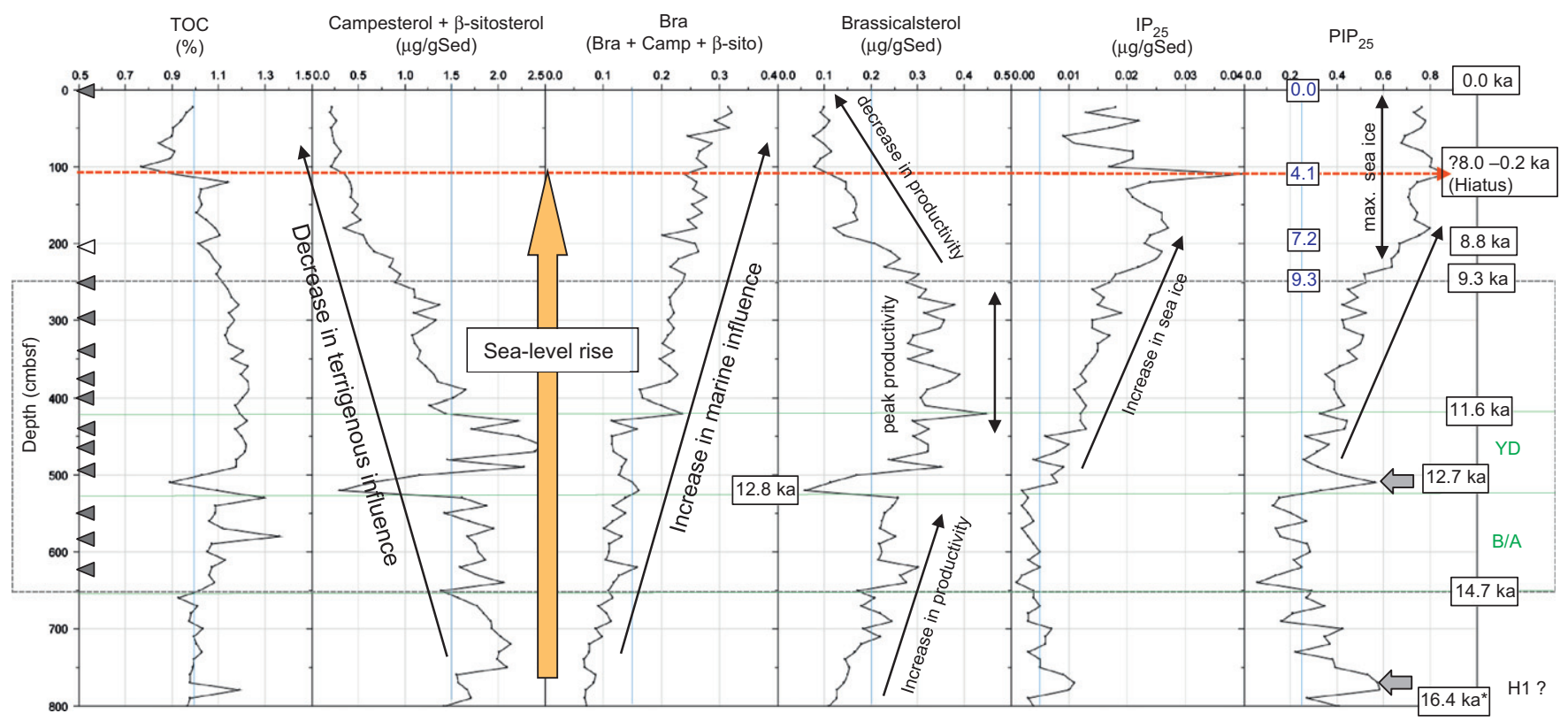

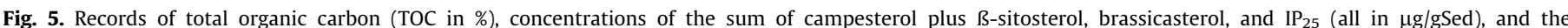

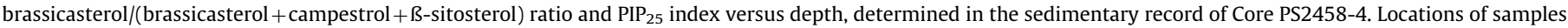

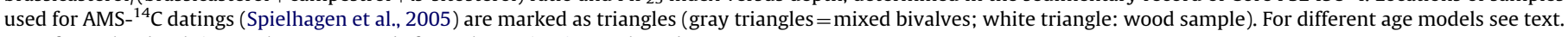
Data from the depth interval 250-650 cmbsf are shown in Fig. 6, plotted versus age.

that this HBI diene might not be a definitive ice proxy biomarker like $\mathrm{IP}_{25}$. Both isomers, however, show a quite similar, mostly parallel variability in the sedimentary record of Core PS2458-4 (data table doi:10.1594/PANGAEA.775891). Such a similarity in the profiles of both $\mathrm{IP}_{25}$ and the HBI diene was also described in a Holocene record of Core ARC-3 recovered in Barrow Strait, northernmost Baffin Bay (see Fig. 1 for location). This as well as the occurrence of the diene in sediments from various sea-ice covered locations around Antarctica are interpreted as strong evidence that these two compounds originate from the same source, i.e., sea-ice diatoms (Vare et al., 2009; Massé et al., 2011). In the Holocene interval of Core PS2458-4, the diene/ $/ \mathrm{IP}_{25}$ ratios display a low variability and are generally low (between 0.8 and 4 ) with a decreasing trend towards the modern (Fig. 6). In the lower (preHolocene) part of the record, on the other hand, higher and much more variable values are typical. In the warmer Bølling-Allerød period, the diene/ $\mathrm{IP}_{25}$ ratios reach maximum values between 20 and 60 (Fig. 6). This observation is consistent with the preferential formation of more unsaturated HBI isomers at higher diatom growth temperatures (Rowland et al., 2001).

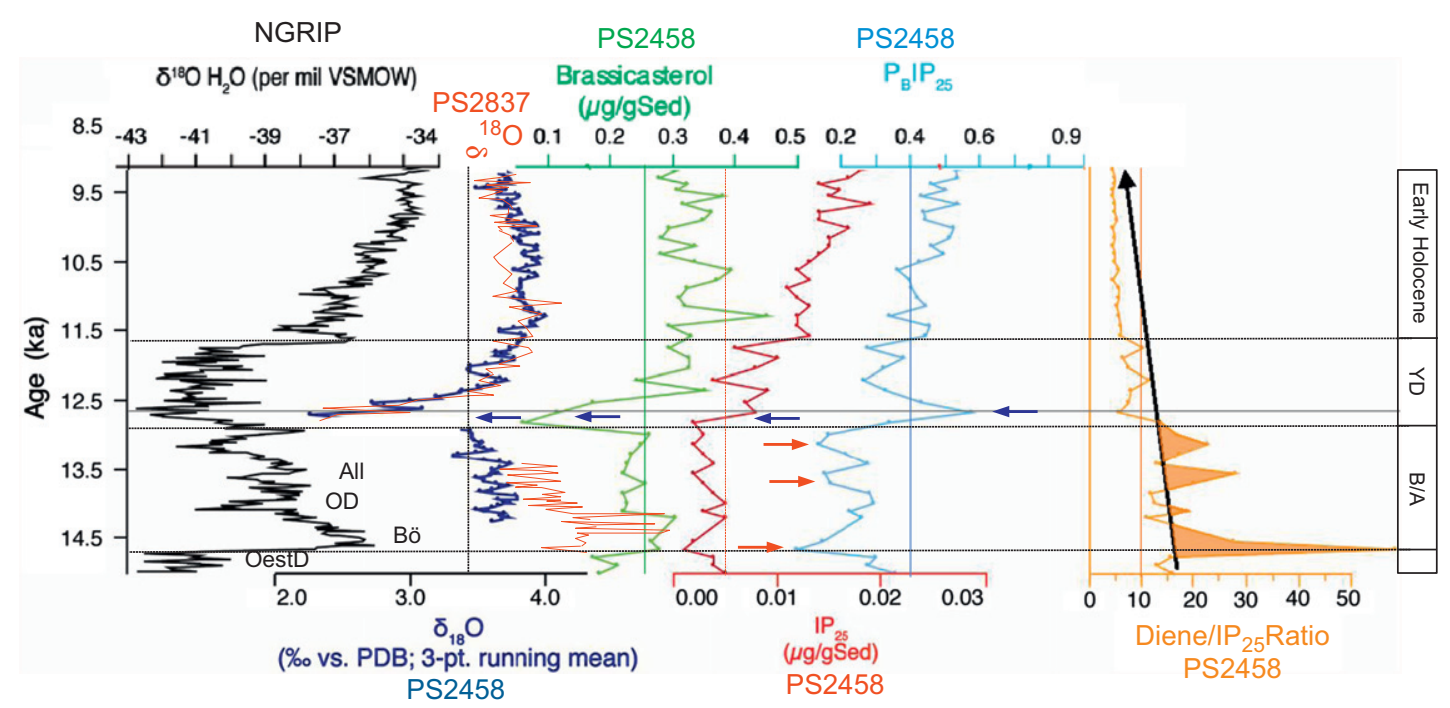

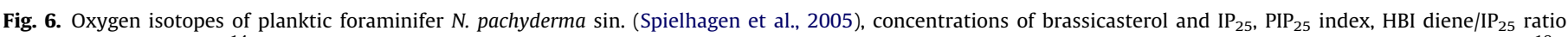

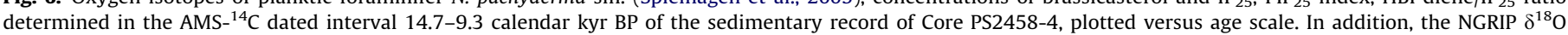

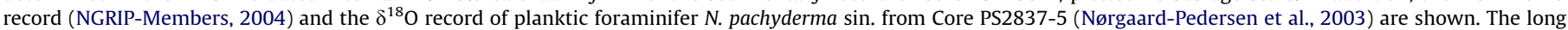

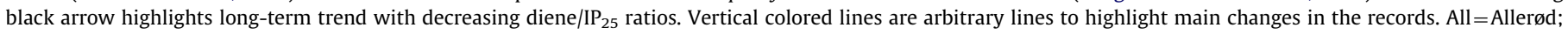

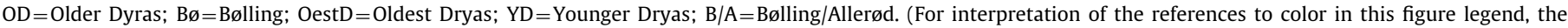
reader is referred to the web version of this article). 
In the following, the history of sea-ice cover at the Laptev Sea continental slope from the Bølling/Allerød warm period towards the Holocene is discussed in more detail.

\subsubsection{The Bølling-Allerød warm period: ice-free conditions at the Laptev Sea continental slope?}

After the Heinrich Event 1 when sea ice was probably somewhat extended as suggested from increased $\mathrm{IP}_{25}$ and $\mathrm{PIP}_{25}$ values, sea ice cover step-wise decreased (Fig. 5). A smaller-scale maximum in $\mathrm{PIP}_{25}$ directly before the Bølling-Allerød boundary, is correlated with the Oldest Dryas cooling Event. With the BøllingAllerød Warm Interval, minimum $\mathrm{IP}_{25}$ and $\mathrm{PIP}_{25}$ values were reached. In detail, PIP $_{25}$ values display three minimum values at 14.6, 13.5, and 13.1 calendar kyr BP, coinciding with distinct maxima in the diene/ $/ \mathrm{IP}_{25}$ ratios (Fig. 6). These data suggest three phases characterized by warmer sea-surface water and more or less ice-free conditions at the Laptev Sea continental slope, interrupted by colder intervals with more sea-ice. The lowermost one, coinciding with $\mathrm{PIP}_{25}$ maximum, probably represent the Older Dryas cold event, based on correlation with the NGRIP Ice Core record. The absolute $\mathrm{IP}_{25}$ minimum and increased phytoplankton biomarker value, resulting in a minimum PIP $_{25}$ ratio of 0.05 , as well as the absolute maximum in the diene $/ \mathrm{IP}_{25}$ ratio of 60 correlate with the peak Bølling warm interval (Fig. 6). That phytoplankton biomarker values remain relatively low for icefree conditions may be explained by still not optimum conditions for phytoplankton productivity due to the strong influence of riverine suspended matter discharge at times lowered sea-level (see Fig. 4). Very similar fluctuations in biogenic sedimentation and productivity during the Bølling-Allerød interstadial were also recorded from the northern Norwegian continental shelf (Knies et al., 2003). In the Bølling peak warm interval, extreme ice-free conditions were described in a sediment core from Fram Strait, contemporaneously with a distinct maximum in phytoplankton productivity (Müller et al., 2009).

\subsubsection{The Younger Dryas Event: freshwater discharge triggers Arctic sea-ice formation and abrupt cooling event?}

Almost contemporaneously with the onset of the Younger Dryas, a huge outflow event of $9.5 \times 10^{3} \mathrm{~km}^{3}$ freshwater (or a flux of $0.30 \mathrm{~Sv}$ if assuming a release within one year; Teller et al., 2002) from the North American glacial Lake Agassiz into the North Atlantic has been proposed, which may have weakened the deep-water formation in the Greenland-Islandic-Norwegian seas and, thus, the thermohaline circulation (THC) during this interval (Broecker et al., 1989; Clark et al., 2002; Teller et al., 2002; McManus et al., 2004). There was, however, an ongoing debate about the pathways of freshwater, i.e., whether the freshwater discharge was directly supplied into the Atlantic Ocean (Broecker et al., 1989) or whether the drainage of Lake Agassiz was towards the Arctic Ocean with a subsequent export of freshwater through Fram Strait into the Atlantic (Fig. 7; Tarasov and Peltier, 2005;

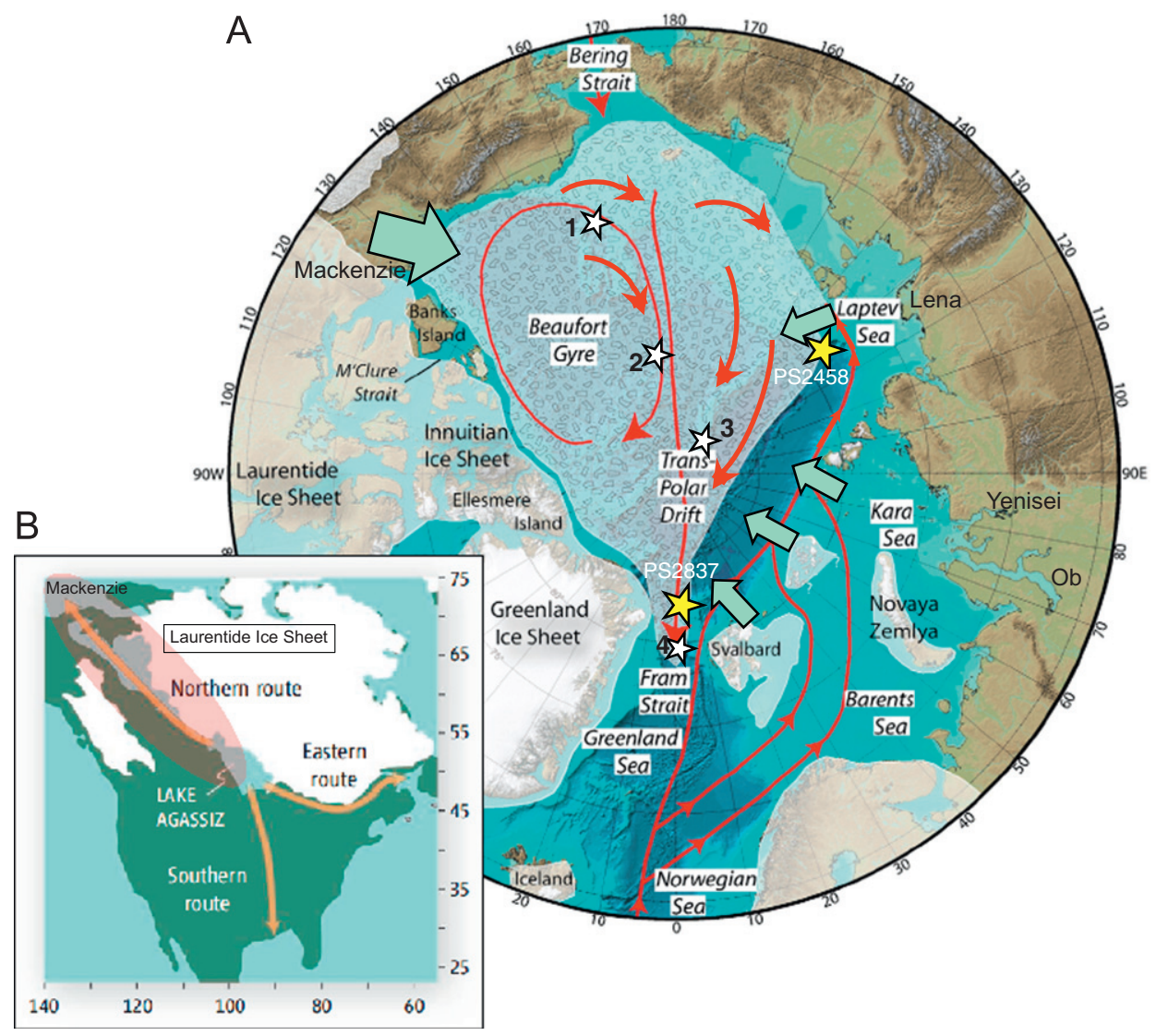

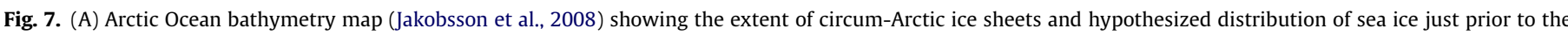

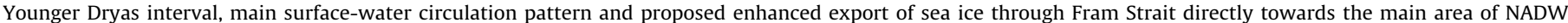

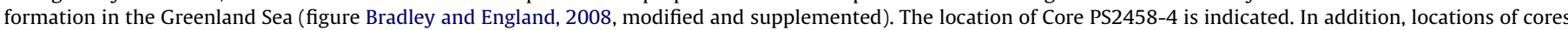

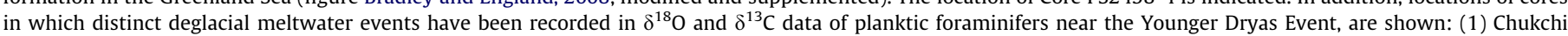

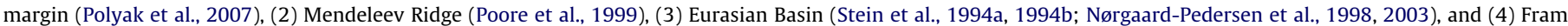

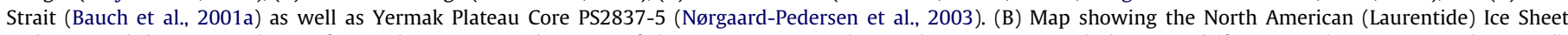

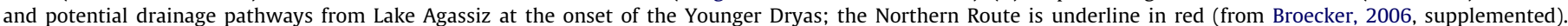
(For interpretation of the references to color in this figure legend, the reader is referred to the web version of this article.) 
Broecker, 2006; Peltier et al., 2006). Peltier et al. (2006) could show that such freshening of the surface of the Arctic Ocean would have been as efficient for shutting down the Atlantic THC as would direct Atlantic freshening. As stated by Broecker (2006), a clear proof of the path taken by the flood was still missing. Very recently, Murton et al. (2010) could identify such a missing flood path, evident from gravels and a regional erosion surface, running through the Mackenzie River system in the Canadian Arctic Coastal Plain. From optically stimulated luminescence dating, these authors have determined the approximate age of this Mackenzie River flood into the Arctic Ocean to be shortly after 13 calendar kyr BP supporting the hypothesis that the trigger of the Younger Dryas cooling was along the Arctic route.

If the latter hypothesis is correct, the freshwater event at the beginning of the Younger Dryas should also be recorded in central Arctic Ocean and Fram Strait sediment cores. During the last deglaciation, indeed, strong meltwater signals are recorded in sharp depletions in $\delta^{18} \mathrm{O}$ as well as $\delta^{13} \mathrm{C}$ values determined in planktic foraminifers in sediment cores from the Mendeleev Ridge and Makarov Basin through the Lomonosov Ridge and Amundsen Basin to the eastern Gakkel Ridge/Nansen Basin region (Fig. 7; Andersson et al., 2003; Stein et al., 1994a, 1994b; Nørgaard-Pedersen et al., 1998, 2003; Poore et al., 1999; Polyak et al., 2007). Very low sedimentation rates, however, make it difficult to clearly identify the Younger Dryas Event in these cores. A 'marine' evidence for a major drainage event in the Canadian Arctic and increased sea ice formation at the onset of the Younger Dryas was proposed from elevated ice-rafted debris with a mineralogical (dolomite) signature indicative for a Canadian origin, found in a sediment core from Lomonosov Ridge close to the North Pole (Not and Hillaire-Marcel, 2012). This sea-ice signal was further carried by the Beaufort Gyre and then Transpolar Drift system into the North Atlantic. A strong meltwater input from the Arctic Ocean into the North Atlantic at that time was also deduced due to the distinct decrease in planktic $\delta^{18} \mathrm{O}$ identified in Yermak Plateau Core PS2837-5 (Nørgaard-Pedersen et al., 2003; see further discussion below) and Fram Strait Core PS1230 (Bauch et al., 2001a) at the beginning of the Younger Dryas interval (Fig. 7).

A clear proof of the Arctic Ocean flood event and its direct relationship to enhanced sea-ice formation and the Younger Dryas cooling event in the central Arctic Ocean, however, is missing so far. We think that this gap in knowledge may be filled by the records of Core PS2458-4 presented and discussed here. In this core, Spielhagen et al. (2005) recorded a very strong freshwater event contemporaneously with the onset of the Younger Dryas (Fig. 6). The exact onset of the rapid outburst of freshwater is somewhat critical as directly below the $\delta^{18} \mathrm{O}$ minimum at 12.7 calendar kyr BP foraminifers are absent in the sediments, interpreted as a drop in salinity below critical limit for foraminifer growth. That means at this time (about 13 calendar kyr BP), probably the maximum freshwater discharge occurred (Spielhagen et al., 2005). These authors interpret this signal as a more local Laptev Sea freshwater event related to increased Lena River discharge. Coincident with the freshwater event, however, the terrestrial biomarkers campesterol and $ß$-sitosterol (indicative for direct terrigenous/fluvial input of higher plants) sharply dropped-down as well (Fig. 6). This may suggest, that the strong freshwater signal determined in the section of Core PS2458-4 is probably less related to local input by the Lena River, but instead freshwater/meltwater input from the western (Canadian) Arctic via surface water circulation might have been more important (Fig. 7). This interpretation is supported by the fact that-in contrast to the Mackenzie area where a large ice sheet still existed in the hinterland during Younger Dryas times-no large-sized ice sheet being a potential meltwater source, existed in the hinterland of the Lena River at that time (Fig. 7; Bradley and England, 2008).
Parallel to the distinct freshwater input, phytoplankton productivity seems to be drastically decreased, followed by a sudden increase in sea-ice cover (Fig. 6). These data support that enhanced freshwater flux may have increased sea-ice formation in the Arctic at the beginning of the Younger Dryas. In combination with the contemporaneous, abrupt and very prominent drop in $\delta^{18} \mathrm{O}$ and $\delta^{13} \mathrm{C}$ observed at Core PS2837-5 and indicative for a freshwater/meltwater pulse in the Yermak Plateau/Fram Strait area (Figs. 6 and 7; Nørgaard-Pedersen et al., 2003), these data are in line with the hypothesis that strongly enhanced freshwater (and ice) export from the Arctic into the North Atlantic may have played a dominant trigger role during the onset of the Younger Dryas cold reversal, as proposed by Tarasov and Peltier (2005) and Bradley and England (2008) (Fig. 7). For testing the importance of Arctic freshwater and sea-ice flux for Younger Dryas environmental change, however, more high-resolution well-dated sea-ice records from the Arctic Ocean are needed.

\subsubsection{The Holocene: increase in sea ice causes decrease in productivity}

During the Holocene, increasing $\mathrm{IP}_{25}$ and $\mathrm{PIP}_{25}$ values indicate a steady increase in sea-ice cover. The Early Holocene time interval between about 11.6 and 9.3 calendar kyr BP is characterized by maximum abundance of the phytoplankton biomarker brassicasterol, interpreted as peak productivity (Figs. 5 and 6). Increased phytoplankton values and higher $\mathrm{IP}_{25}$ and $\mathrm{PIP}_{25}$ values may suggest an iceedge situation with increased phytoplankton productivity and sea-ice algae at that time (cf., Fig. 2). In the upper $200 \mathrm{cmbsf}$, i.e., during the last 7.2 or 8.8 calendar kyr BP (depending on the age model; see below), $\mathrm{IP}_{25}$ and $\mathrm{PIP}_{25}$ values significantly increased reaching their absolute maximum values (Fig. 5). Contemporaneously, the phytoplankton biomarker brassicasterol decreased. The decrease in productivity is probably caused by the increase in sea ice, i.e., during this time interval sea-ice conditions deteriorated towards more a closed sea-ice cover similar to conditions we have today.

Concerning the two age models mentioned in Section 2, we cannot absolutely prove or disprove one or the other. The correlation with sedimentation rate records from the Laptev and Kara seas continental margin (Section 2) as well as other climate records from the Eurasian Arctic, however, may support the alternative age model, i.e., that the uppermost $200 \mathrm{cmbsf}$ represent extended sea-ice cover during the last about 7.2 calendar kyr BP. In two sediment cores from the western Laptev Sea (see Fig. 4 for core locations), for example, Taldenkova et al. (2010) studied ice-rafted debris (IRD) and Atlantic-Water indicative foraminifers and conclude that after about 7 calendar kyr BP climate cooling and enhanced Atlantic-derived water inflow caused re-growth of ice caps on Severnaya Zemlya leading to a recurrence of IRD. Contemporaneously, IRD input at the western Barents Sea continental slope (Sarnthein et al., 2003) as well as the sea-ice cover along the western Svalbard continental slope (Müller et al., 2009, 2012) also increased, supporting this general cooling trend.

\section{Conclusions}

- The novel sea ice proxies $\mathrm{IP}_{25}$ and $\mathrm{PIP}_{25}$ in sediment trap samples and a sediment core from the southern Lomonosov Ridge/Laptev Sea continental slope area allowed a detailed (semi-quantitative) reconstruction of modern seasonal variability and deglacial/Holocene change of Arctic sea-ice cover.

- The sediment trap data indicate a predominantly permanent sea ice cover at the trap location between November 1995 and June 1996, an ice-edge situation with increased phytoplankton productivity and sea-ice algae input in July/August 1996, and the start of new-ice formation in late September. 
- During the Bølling-Allerød Warm Interval, minimum $\mathrm{PIP}_{25}$ values indicative for minimum sea-ice cover, were reached. In detail, these data suggest three phases of warmer sea-surface water and more or less ice-free conditions at the southern Lomonosov Ridge/Laptev Sea continental slope area, interrupted by colder intervals with more sea-ice.

- The new biomarker data indicate an abrupt increase in Arctic Ocean sea-ice cover at the beginning of the Younger Dryas, immediately following a sudden freshwater/meltwater event. These data are in line with the hypothesis that a huge freshwater outburst into the Arctic Ocean, related increase in sea-ice formation, and subsequent freshwater and sea-ice export into the North Atlantic via Fram Strait may have been a potential trigger mechanism for the Younger Dryas cooling event.

- During the Holocene, increasing $\mathrm{IP}_{25}$ and $\mathrm{PIP}_{25}$ values indicate a steady increase in sea-ice cover, with a more or less perennial sea-ice cover similar to that of today probably reached at about 7-8 calendar kyr BP.

\section{Acknowledgment}

We gratefully thank Walter Luttmer and Robert Karandi for technical assistance. Special thanks to Robert Spielhagen, Henning Bauch (both GEOMAR Kiel) and Eva-Maria Nöthig for fruitful discussions. Many thanks to the two anonymous reviewers of this paper for numerous constructive suggestions improving the manuscript. Supplementary data associated with this publication are available at doi:10.1594/PANGAEA.775891.

\section{Appendix. Supplementary materials}

Supplementary data associated with this article can be found in the online version at http://dx.doi.org/10.1016/j.epsl.2012.07.009.

\section{References}

Andersson, C., Risebrobakken, B., Jansen, E., Dahl, S.O., 2003. Late Holocene surface ocean conditions of the Norwegian Sea (Vøring Plateau). Paleoceanography 18 (2), 1044.

Bauch, H.A., Erlenkeuser, H., Spielhagen, R.F., Struck, U., Matthiessen, J., Thiede, J., Heinemeier, J., 2001a. A multiproxy reconstruction of the evolution of deep and surface waters in the subarctic Nordic seas over the last 30,000 yr. Quat. Sci. Rev. 20 (4), 659-678.

Bauch, H.A., Mueller-Lupp, T., Taldenkova, E., Spielhagen, R.F., Kassens, H., Grootes, P.M., Thiede, J., Heinemeier, J., Petryashov, V.V., 2001b. Chronology of the Holocene transgression at the north Siberian margin. Glob. Planet. Change 31, $125-139$.

Belt, S.T., Massé, G., Rowland, S.J., Poulin, M., Michel, C., LeBlanc, B., 2007. A novel chemical fossil of palaeo sea ice: $\mathrm{IP}_{25}$. Org. Geochem. 38 (1), 16-27.

Belt, S.T., Massé, G., Vare, L.L., Rowland, S.J., Poulin, M., Sicre, M.-A., Sampei, M., Fortier, L., 2008. Distinctive ${ }^{13} \mathrm{C}$ isotopic signature distinguishes a novel sea ice biomarker in Arctic sediments and sediment traps. Mar. Chem. 112 (3-4), $158-167$.

Belt, S.T., Vare, L.L., Massé, G., Manners, H.R., Price, J.C., MacLachlan, S.E., Andrews, J.T., Schmidt, S., 2010. Striking similarities in temporal changes to spring sea ice occurrence across the central Canadian Arctic Archipelago over the last 7000 yr. Quat. Sci. Rev. 29 (25-26), 3489-3504.

Boon, J.J., Rijpstra, W.I.C., Lange, F.d., de Leeuw, J.W., Yoshioka, M., Shimizu, Y., 1979. Black Sea sterol—a molecular fossil for dinoflagellate blooms. Nature 277, 125-127.

Boucsein, B., Knies, J., Stein, R., 2002. Organic matter deposition along the Kara and Laptev Sea continental margin (eastern Arctic Ocean) during last deglaciation and Holocene: evidence from organic-geochemical and petrographical data. Mar. Geol. 183, 67-87.

Bradley, R.S., England, J.H., 2008. The Younger Dryas and the Sea of Ancient Ice 70, 1-10Quat. Res. 70, 1-10.

Broecker, W.S., 2006. Was the Younger Dryas triggered by a flood? Science 312, 1146-1148.
Broecker, W.S., Kennett, J.T., Flower, B.P., Teller, J.T., Trumbore, S., Bonani, G. Wolfli, W., 1989. Routing of meltwater from the Laurentide Ice Sheet during the Younger Dryas cold episode. Nature 341, 318-320.

Brown, T.A., Belt, S.T., 2012. Identification of the sea ice diatom biomarker IP25 in Arctic benthic macrofauna: direct evidence for a sea ice diatom diet in Arctic heterotrophs. Polar Biol. 35, 131-137.

Brown, T.A., Belt, S.T., Piepenburg, D., 2012. Evidence for a pan-Arctic sea-ice diatom diet in Strongylocentrotus spp. Polar Biol., http://dx.doi.org/10.1007/ s00300-012-1164-9.

Clark, P.U., Pisias, N.G., Stocker, T.F., Weaver, A.J., 2002. The role of the thermohaline circulation in abrupt climate change. Nature 415 (6874), 863-869.

Fahl, K., Nöthig, E.-M., 2007. Lithogenic and biogenic particle fluxes on the Lomonosov Ridge (central Arctic Ocean) and their relevance for sediment accumulation: vertical vs. lateral transport. Deep Sea Res. I 54 (8), 1256-1272.

Fahl, K., Stein, R., 1999. Biomarkers as organic-carbon-source and environmental indicators in the Late Quaternary Arctic Ocean: problems and perspectives. Mar. Chem. 63 (3-4), 293-309.

Fairbanks, R.G., 1989. A 17,000-yr glacio-eustatic sea level record: influence of glacial melting rates on the Younger Dryas event and deep-ocean circulation. Nature 342, 637-642.

Francis, J.A., Hunter, E., Key, J.R., Wang, X., 2005. Clues to variability in Arctic minimum sea ice extent. Geophys. Res. Lett. 32 (L21501), 1-4.

Fütterer, D.K., 1994. The expedition ARCTIC93 Leg ARK-IX/4 of RV "Polarstern" 1993. Rep. Polar Res. 149, 244.

Jakobsson, M., Macnab, R., Mayer, L., Anderson, R., Edwards, M., Hatzky, J., Schenke H.-W., Johnson, P., 2008. An improved bathymetric portrayal of the Arctic Ocean: implications for ocean modeling and geological, geophysical and oceanographic analyses. Geophys. Res. Lett. 35, L07602, http://dx.doi.org/ 10.1029/2008GL033520.

Johannessen, O.M., Bengtsson, L., Miles, M.W., Kuzmina, S.I., Semenov, V.A., Alekseev, G.V., Nagurnyi, A.P., Zakharov, V.F., Bobylev, L.P., Pettersson, L.H. Hasselmann, K., Cattle, H.P., 2004. Arctic climate change: observed and modelled temperature and sea-ice variability. Tellus A 56, 328-341.

Johns, L., Wraige, E.J., Belt, S.T., Lewis, C.A., Masse, G., Robert, J.M., Rowland, S.J., 1999. Identification of a C-25 highly branched isoprenoid (HBI) diene in Antarctic sediments, Antarctic sea-ice diatoms and cultured diatoms. Org. Geochem. 30 (11), 1471-1475.

Knies, J., Hald, M., Ebbesen, H., Mann, U., Vogt, C., 2003. A deglacial-middle Holocene record of biogenic sedimentation and paleoproductivity changes from the northern Norwegian continental shelf. Paleoceanography 18, 4

Massé, G., Belt, S.T., Crosta, X., Schmidt, S., Snape, I., Thomas, D.N., Rowland, S.J., 2011. Highly branched isoprenoids as proxies for variable sea ice conditions in the Southern Ocean. Antarct. Sci. 23, 487-498.

Massé, G., Rowland, S.J., Sicre, M.-A., Jacob, J., Jansen, E., Belt, S.T., 2008. Abrupt climate changes for Iceland during the last millennium: evidence from high resolution sea ice reconstructions. Earth Planet. Sci. Lett. 269, 565-569.

McManus, J.F., Francois, R., Gherardi, J.-M., Keigwin, L.D., Brown-Lager, S., 2004. Collapse and rapid resumption of Atlantic meridional circulation linked to deglacial climate changes. Nature 428, 834-837.

Müller, J., Massé, G., Stein, R., Belt, S.T., 2009. Variability of sea-ice conditions in the Fram Strait over the past 30,000 yr. Nat. Geosci. 2 (11), 772-776.

Müller, J., Wagner, A., Fahl, K., Stein, R., Prange, M., Lohmann, G., 2011. Towards quantitative sea ice reconstructions in the northern North Atlantic: a combined biomarker and numerical modelling approach. Earth Planet. Sci. Lett. 306 (3-4), 137-148.

Müller, J., Werner, K., Stein, R., Fahl, K., Moros, M., Jansen, E., 2012. Holocene cooling culminates in sea ice oscillations in Fram Strait. Quat. Sci. Rev. 47 1-14, http://dx.doi.org/10.1016/j.quascirev.2012.04.024.

Murton, J.B., Bateman, M.D., Dallimore, S.R., Teller, J.T., Yang, Z., 2010. Identification of Younger Dryas outburst flood path from Lake Agassiz to the Arctic Ocean. Nature 464 (7289), 740-743.

NGRIP-Members, 2004. High-resolution record of Northern Hemisphere climate extending into the last interglacial period. Nature 431 (7005), 147-151.

Nørgaard-Pedersen, N., Spielhagen, R.F., Erlenkeuser, H., Grootes, P.M., Heinemeier J., Knies, J., 2003. Arctic Ocean during the Last Glacial Maximum: Atlantic and polar domains of surface water mass distribution and ice cover. Paleoceanography 18 (3), 1063-1082.

Nørgaard-Pedersen, N., Spielhagen, R.F., Thiede, J., Kassens, H., 1998. Central Arctic surface ocean environment during the past 80,000 yr. Paleoceanography 13 , 193-204.

Not, C., Hillaire-Marcel, C., 2012. Enhanced sea-ice export from the Arctic during the Younger Dryas. Nat. Commun. 3, 647, http://dx.doi.org/10.1038/ ncomms1658.

Peltier, W.R., Vettoretti, G., Stastna, M., 2006. Atlantic meridional overturning and climate response to Arctic Ocean freshening. Geophys. Res. Lett. 33, L06713, http://dx.doi.org/10.1029/2005GL025251.

Polyak, L.V., Darby, D.A., Bischoff, J.F., Jakobsson, M., 2007. Stratigraphic constraints on late Pleistocene glacial erosion and deglaciation of the Chukchi margin. Arct. Ocean Quat. Res. 67, 234-245.

Polyakov, I.V., Johnson, M.A., 2000. Arctic decadal and interdecadal variability. Geophys. Res. Lett. 27 (24), 4097-4100.

Polyakov, I.V., Johnson, M.A., Colony, R.L., Bhatt, U., Alekseev, G.V., 2002. Observationally based assessment of polar amplification of global warming. Geophys. Res. Lett. 29, 1878. 
Poore, R.Z., Osterman, L., Curry, W.B., Phillips, R.L., 1999. Late Pleistocene and Holocene meltwater events in the western Arctic Ocean. Geology 27 (8), 759-762.

Rachor, E., 1997. Scientific cruise report of the Arctic expedition ARK-XI/1 of RV "Polarstern" in 1995. Rep. Polar Res. 226, 157.

Rowland, S.J., Belt, S.T., Wraige, E.J., Masse, G., Roussakis, C., Robert, J.M., 2001. Effects of temperature on polyunsaturation in cytostatic lipids of Haslea ostrearia. Phytochemistry 56 (6), 597-602.

Sakshaug, E., 2004. Primary and secondary production in the Arctic Seas. In: Stein, R. Macdonald, R.W. (Eds.), The Organic Carbon Cycle in the Arctic Ocean. SpringerVerlag, Heidelberg, pp. 57-82.

Sarnthein, M., Van Kreveld, S., Erlenkeuser, H., Grootes, P.M., Kucera, M., Pflaumann, U., Schulz, M., 2003. Centennial-to-millennial-scale periodicities of Holocene climate and sediment injections off the western Barents shelf, $75^{\circ} \mathrm{N}$. Boreas $32(3), 447-461$.

Serreze, M.C., Holland, M.M., Stroeve, J., 2007. Perspectives on the Arctic's shrinking sea-ice cover. Science 315 (5818), 1533-1536.

Spielhagen, R., Siegert, C., Erlenkeuser, H., 2005. History of freshwater runoff across the Laptev Sea (Arctic) during the last deglaciation. Glob. Planet. Change 48, 187-207.

Spielhagen, R.F., Erlenkeuser, H., Heinemeier, J., 1996. Deglacial changes of freshwater export from the Laptev Sea to the Arctic Ocean. Quaternary Environment of the Eurasian North (QUEEN). Strasbourg (pp. abstract volume)

Stein, R., 2008. Arctic Ocean Sediments: Processes, Proxies, and Paleoenvironment. Developments in Marine Geology, vol. 2. Elsevier, Amsterdam (592 pp.).

Stein, R., Boucsein, B., Fahl, K., Garcia de Oteyza, T., Knies, J., Niessen, F., 2001 Accumulation of particulate organic carbon at the Eurasian continental margin during late Quaternary times: controlling mechanisms and paleoenvironmental significance. Glob. Planet. Change 31 (1-4), 87-104.

Stein, R., Dittmers, K., Fahl, K., Kraus, M., Matthiessen, J., Niessen, F., Pirrung, M. Polyakova, Y., Schoster, F., Steinke, T., Fütterer, D.K., 2004. Arctic (palaeo) river discharge and environmental change: evidence from the Holocene Kara Sea sedimentary record. Quat. Sci. Rev. 23 (11-13), 1485-1511.

Stein, R., Fahl, K., 2000. Holocene accumulation of organic carbon at the Laptev Sea Continental Margin (Arctic Ocean): sources, pathways, and sinks. Geo-Mar. Lett. 20, 27-36.

Stein, R., Fahl, K., 2004. The Laptev Sea: distribution, sources, variability and burial of organic carbon. In: Stein, R., Macdonald, R.W. (Eds.), The Organic Carbon Cycle in the Arctic Ocean. Springer, Berlin, pp. 213-237.
Stein, R., Müller, J., Fahl, K. Proxy reconstruction of Arctic Ocean sea ice history: from IRD to $\mathrm{IP}_{25}$ and $\mathrm{PIP}_{25}$. Polarforschung, submitted for publication.

Stein, R., Nam II, S., Schubert, C., Vogt, C., Futterer, D., Heinemeier, J., 1994a. The last deglaciation event in the Eastern Central Arctic Ocean. Science 264 (5159), 692-696.

Stein, R., Schubert, C., Vogt, C., Fütterer, D., 1994b. Stable isotope stratigraphy, sedimentation rates, and salinity changes in the Latest Pleistocene to Holocene eastern central Arctic Ocean. Mar. Geol. 119 (3-4), 333-355.

Stroeve, J., Holland, M., Meier, M., Scambos, W., Serreze, M., T., 2007. Arctic sea ice decline: faster than forecast. Geophys. Res. Lett. 34 (L09501), 1-5.

Svendsen, J.I., Alexanderson, H., Astakhov, V.I., Demidov, I., Dowdeswell, J.A. Funder, S., Gataullin, V., Henriksen, M., Hjort, C., Houmark-Nielsen, M., Hubberten, H.W., Ingolfsson, O., Jakobsson, M., Kjär, K.H., Larsen, E., Lokrantz, H., Lunkka, J.P., Lysa, A., Mangerud, J., Matiouchkov, A., Murray, A., Müller, P., Niessen, F., Nikolskaya, O., Polyak, L., Saarnisto, M., Siegert, C., Siegert, M.J., Spielhagen, R.F., Stein, R., 2004. Late Quaternary ice sheet history of northern Eurasia. Quat. Sci. Rev. 23 (11-13), 1229-1271.

Taldenkova, E., Bauch, H.A., Gottschalk, J., Nikolaev, S., Rostovtseva, Y., Pogodina, I., Ovsepyan, Y., Kandiano, E., 2010. History of ice-rafting and water mass evolution at the northern Siberian continental margin (Laptev Sea) during Late Glacial and Holocene times. Quat. Sci. Rev. 29, 3919-3935.

Tarasov, L., Peltier, W.R., 2005. Arctic freshwater forcing of the Younger Dryas cold reversal. Nature 435, 662-665.

Teller, J.T., Leverington, D.W., Mann, J.D., 2002. Freshwater outbursts to the oceans from glacial Lake Agassiz and their role in climate change during the last deglaciation. Quat. Sci. Rev. 21 (8-9), 879-887.

Vare, L.L., Massé, G., Belt, S.T., 2010. A biomarker-based reconstruction of sea ice conditions for the Barents Sea in recent centuries. Holocene, http://dx.doi.org/ $10.1177 / 0959683609355179$.

Vare, L.L., Massé, G., Gregory, T.R., Smart, C.W., Belt, S.T., 2009. Sea ice variations in the central Canadian Arctic Archipelago during the Holocene. Quat. Sci. Rev. 28 (13-14), 1354-1366.

Venegas, S.A., Mysak, L.A., 2000. Are there natural time scales of climate variability in the Arctic? J. Clim. 13, 3412-3434.

Volkman, J.K., 1986. A review of sterol markers for marine and terrigenous organic matter. Org. Geochem. 9 (2), 83-99.

Zernova, V.V., Nöthig, E.-M., Shevchenko, V.P., 2000. Vertical microalgae flux in the northern Laptev Sea. Oceanology 40, 801-808. 